\title{
EVALUATION OF HERBICIDE TREATMENTS FOR CONTROL OF WILD GLADIOLUS (GLADIOLUS SEGETUM) IN WHEAT
}

\author{
MAJD, R. ${ }^{1}$ - ChAMANABAD, H. R. M. ${ }^{1}$ - ZAND, E. ${ }^{2}$ - MoHEBOdini, M. ${ }^{3}-$ KHIAVI, H. K. ${ }^{4}-$ \\ ALEBRAHIM, M. T. $.^{*}-$ TSENG, T. M. ${ }^{5}$ \\ ${ }^{I}$ Department of Agronomy and Plant Breeding, Faculty of Agriculture and Natural Resources \\ University of Mohaghegh Ardabili, Ardabil, Iran (phone: +98-9123501493) \\ ${ }^{2}$ Department of Weed Research, Iranian Institute of Plant Protection, Tehran, Iran \\ ${ }^{3}$ Department of Horticulture, Faculty of Agriculture and Natural Resource \\ University of Mohaghegh Ardabili, Ardabil, Iran \\ ${ }^{4}$ Department of Plant Protection Research, Ardabil Agriculture and Natural Resources \\ Research and Education center, Ardabil, Iran \\ ${ }^{5}$ Department of Plant and Soil Sciences, Mississippi State University \\ Mississippi State, Mississippi, USA (phone: +1-662-325-4725; fax: +1-662-325-8742) \\ ${ }^{*}$ Corresponding author \\ email:m_ebrahim@uma.ac.ir; phone:+98-9123501493 \\ (Received $18^{\text {th }}$ Dec 2018; accepted $28^{\text {th }}$ Feb 2019)
}

\begin{abstract}
Wild gladiolus (Gladiolus segetum) is a problematic weed in dry land winter wheat fields of northwest and west provinces in Iran, and accounts for about $23 \%$ of yield losses in winter wheat. Greenhouse studies were conducted from 2014 to 2015 to evaluate different herbicide treatments to control of the noxious weed, Gladiolus segetum, commonly found in northwest of Iran. The objective was to evaluate potential control possibilities with commercial herbicides containing sulfosulfuron (Apirus ${ }^{\circledR}$ ), mesosulfuron+ idosulfuron (Atlantis $\AA$ ), mesosulfuron-methyl + Iodosulfuron-methyl-sodium + Diflufenican (Othello $\AA)$, metsulfuron-methyl + sulfosulfuron(Total $\left.{ }^{\circledR}\right)$, clodinafop-propargyl (Topik $\left.®\right)$, and glyphosate. Herbicides were applied to fully developed stems $(10 \mathrm{~cm})$, at the 2-3 leaf stage of the weed which coincides with the tillering stage in wheat. Similar to sulfosulfuron and mesosulfuron + idosulfuron, higher rates of glyphosate resulted in higherbiomass reduction of $G$. segetumin both years. But the application rates of glyphosate were remarkably higher compared to sulfosulfuron and mesosulfuron + idosulfuron. The $\mathrm{ED}_{50}$ values of glyphosate were 1751.99 and $1919.93 \mathrm{~g}^{\text {ai ha }}{ }^{-1}$, and the $\mathrm{ED}_{90}$ values were 6349.96 and $7031.84 \mathrm{~g}$ ai ha ${ }^{-1}$, in 2014 and 2015 , respectively.
\end{abstract}

Keywords: dose response, dry weight, effective dose, noxious weed, weed management

\section{Introduction}

Gladiolus spp. from the Iridaceae family (subfamily of Crocoideaehas) is distributed in Africa, the Mediterranean basin, and Western Asia. It is a large genus that includes approximately 300 species (Goldblatt et al., 2001). Gladiolus segetum Ker Gawl and G. italicus Mill. are important weeds in dry land winter wheat fields of the Ardabil province in Iran (Ebadi et al., 2004-2007). The species can be identified by a set of characteristics such as narrow leaves, parallel venation, lowest leaf reduced to a subterranean sheathing cataphyll, and tubular or funnel-shaped perianth with synsepalous sepals (Davis, 1984; Dahlgren, 1985). Wild gladiolus (Gladiolus segetum) is a native weed in Greece, Turkey, Iraq, and Iran. They invade disturbed fields in the northern and western parts of Iran, particularly wheat, legume and other dryland fields (Rashed Mohassel et al., 2001; Majd et al., 2017). It is a major 
constraint to wheat production in Iran, accounting for about $23 \%$ of yield losses (Khalaghani, 2008); and weed control in winter wheat relies almost exclusively on herbicides (DeihimFard and Zand, 2006).

Since wild gladiolus has high vigor and emerges simultaneously with winter wheat, it can become dominant and has the potential to cause heavy yield losses in infested wheat fields. It is thus necessary to identify strategies to effectively manage this problematic weed as like as others which can be nonchemical including fertilizer management had beneficial effect against Velvetleaf (Aghaie et al., 2013), physical (Majd et al., 2017) or chemical by applying new herbicides or using alternative herbicide to delay resistance (Alebrahim et al., 2017; Tahmasebi et al., 2018). Additionally, since wheat fields in different regions of Iran have variable climatic conditions, there is a need to tailor weed control strategies specific to each region. Finding an effective weed control strategy will greatly depend on the use of herbicides at effective doses; therefore, selecting an appropriate herbicide and dose is most important. Ebadi et al. (2015) reported that biomass of wild gladiolus was reduced by incorporating cultural strategies with herbicide mixtures such as clodinafop-propargyl, difenzoquat $+2,4-\mathrm{D}$, Topik $+2,4-\mathrm{D}$, clodinafoppropargyl + tribenuron-methyl, and glyphosate + fallow. The above mentioned mixtures had no differences in their effect on wild gladiolus. The highest and lowest percentage of biomass reduction was obtained by hand weeding and spraying with 2,4-D, respectively. In addition, their results revealed that clodinafop-propargyl controlled wild gladiolus and other weeds results in an increase in crop yield.

Herbicide dose response curves help determine the selectivity and efficacy of herbicides and in some situations help unravel the dose-range for effective weed control and minimal crop damage. Relationships of dose response depends on the weed species, range of doses used, herbicide type, and various environmental conditions, such as temperature, humidity, wind velocity, $\mathrm{CO}_{2}$ and $\mathrm{O}_{2}$ levels, and geographical altittude (Streibig et al., 1993). In our current study we selected several herbicides that belong to three mode-of-action groups: acetolactate synthase (ALS) inhibitors (including mesosulfuron-methyl + iodosulfuron-methyl-sodium + diflufenican, mesosulfuron + idosulfuron, metsulfuron-methyl + sulfosulfuron, and sulfosulfuron), inhibitors of aromatic amino acid biosynthesis (including glyphosate), and acetyl-CoA carboxylase inhibitors (including clodinafop-propargyl). Herbicides such as the pyrimidinyl salicylates (Shimizu et al., 1994), triazolopyrimidine sulfonamide (Subramanian and Gerwick, 1989), imidazolinone (Shaner et al., 1984), and sulfonylurea (LaRossa and Schloss, 1984; Ray, 1984) herbicides has ALS as their primary target site of action. The ALS enzyme catalyzes the biosynthetic pathway for the production of three branchedchain amino acids such as valine, leucine and isoleucine. Exposure of plants to ALSinhibitors therefore inhibits production of the three branched-chain amino acids.

Glyphosate [N-(phosphonomethyl)glycine], is a nonselective, broad spectrum herbicide discovered in 1971 (Baird et al., 1971), and was introduced in 1974 (Franz et al., 1997). Glyphosate was one of the first commercially important herbicide whose site of action was characterized as a single target enzyme in plants, and is the only herbicide known to inhibit 5-enolpyruvylshikimate 3-phosphate synthase (EPSPS). EPSPS catalyzes the penultimate reaction of the shikimate (Shk) pathway (Gruys and Sikorski, 1999) in certain bacteria and plants.

The cyclohexanediones (CHD) and aryloxyphenoxypropanoates (AOPP) inhibits the plastidic enzyme acetyl-CoA carboxylase (ACCase). CHD and AOPP herbicides are used to control a wide selection of grass weeds in both monocot and dicot crops. The basis of 
selectivity differs between dicot and grasses: in dicots, tolerance is based on the inherent insensitivity of the ACCase to these herbicides, whereas in certain cereal crops, selectivity is based on higher rates of herbicide detoxification in the crop species (Devine and Shimabukuro, 1994).

The goal of our study was to compare the efficacy of different herbicides treatments, sulfosulfuron (Apirus ${ }^{\circledR}$ ), mesosulfuron + idosulfuron (Atlantis ${ }^{\circledR}$ ), mesosulfuron methyl + iodosulfuron-methyl-sodium + diflufenican (Othello $($ ) , metsulfuron-methyl + sulfosulfuron (Total $\left.{ }^{\circledR}\right)$, clodinafop-propargyl (Topik ${ }^{\circledR}$ ), and glyphosate (Roundup ${ }^{\circledR}$ ), on the dry weight of wild gladiolus populations. These herbicides were selected because they are primarily used for weed control in wheat in Iran.

\section{Materials and Methods}

\section{Study sites}

Experiments were carried out from May 20, 2014 to August 22, 2014 and from May 20, 2015 to August 22, 2015 in the research greenhouse located in the College of Agriculture and Natural Resources, University of Mohaghegh Ardabili (longitude $48^{\circ} 17.600^{\prime} 20.72 " \mathrm{E}$, latitude $38^{\circ} 12.607^{\prime} 29.51^{\prime \prime} \mathrm{N}$, and 1,386 m altitude), Ardabil, Iran.

\section{Experimental design and treatments}

The experiment was a completely randomized design (CRD) with 4 replications, and were independently repeated in time. Six herbicides with a range of doses were applied and the dry weight of gladiolus measured (Table 1). In April 2014, mature corms of wild gladiolus were collected from several fields of north-western part of Iran, from Germi city; located near Ardabil at longitude 48 9' 24.46" E, latitude $39^{\circ} 6^{\prime} 36.20^{\prime \prime} \mathrm{N}$, and 1,350 $\mathrm{m}$ altitude. The rate per hectare was calculated based on the surface area of the pot $(942$ $\mathrm{cm}^{2}$ ). Herbicides were applied using a $\mathrm{CO}_{2}$-pressurized backpack sprayer fitted with 8002 VS flat fan nozzles, MATABI model, calibrated to a deliver $250 \mathrm{~L} \mathrm{ha}^{-1}$ at $276 \mathrm{KPa}$, while maintaining the constant speed of 4.8 KPH. Herbicides were applied to fully developed stems $(10 \mathrm{~cm})$, at the two-to-three leaf stage of the weed and coincided with the tillering stage of wheat. Irrigation was performed every week from the begging to end of experiments. Temperature was $19-25^{\circ} \mathrm{C}$. Fertigation by using NPK (20:20:20) was done during experimets.

Table 1. List of herbicides used in the study

\begin{tabular}{|c|c|c|}
\hline Herbicide & Rate (g ai ha-1) & $\begin{array}{c}\text { Recommended Rate for Wheat in } \\
\text { Iran (g ai ha-1) } \\
\text { (Zand et al., 2017) }\end{array}$ \\
\hline Sulfosulfuron (Apirus ${ }^{\circledR}$ ) & $0,3.75,7.5,15,22.5,30$ & 20 \\
\hline Mesosulfuron + Idosulfuron (Atlantis ${ }^{\circledR}$ ) & $0,6,18,24,30,36$ & 24 \\
\hline $\begin{array}{l}\text { Mesosulfuron-methyl + Iodosulfuron- } \\
\text { methyl-sodium + Diflufenican (Othello }{ }^{\circledR} \text { ) }\end{array}$ & $0,33,66,82.5,99,132$ & 96 \\
\hline $\begin{array}{c}\text { Metsulfuron-methyl + sulfosulfuron } \\
\left(\text { Total }^{\mathbb{Q}}\right)\end{array}$ & $0,22.5,27,31.5,36,40.5,45$ & 33 \\
\hline Clodinafop-propargyl (Topik $\left.{ }^{\circledR}\right)$ & $0,0.032,0.064,0.080,0.096,0.128$ & 60 \\
\hline Glyphosate $^{\circledR}$ & $0,1025,1230,1435,1640,1845$ & 1600 \\
\hline
\end{tabular}




\section{Sampling procedure}

Shoots of weeds were collected from the soil surface in each pot, four weeks after herbicide treatment application. After drying in an oven at $70^{\circ} \mathrm{C}$ (for $72 \mathrm{~h}$ ) dry weights were measured.

\section{Statistical analysis}

The dry weight per pot, y, was estimated using a log-logistic dose-response model with dose $\mathrm{x}$ in ai/haby R software:

$$
y=\frac{d}{1+\exp \left(b \cdot\left[\log (x)-\log \left(E D_{50}\right)\right]\right)}
$$

where, $\mathrm{b}$ denotes the relative slope around $\mathrm{ED}_{50}$ (Effective Dose), which is the dose required to produce one-half of the dry-weight relative to the upper limit, d. The doseresponse curve takes a snapshot of the dry matter production at the time of harvesting the biomass (Ritz et al., 2006).

\section{Results}

The analysis of residuals and test for lack of fit $(p<0.05)$ confirmed the assumption that the data had constant variance, were normally distributed, and the dose-response curves described the variation in data. The efficacy of the herbicides were compared based on the $\mathrm{ED}_{50}$ and $\mathrm{ED}_{90}$ levels (Tables 2, 3, 4 and 5). As noted in Figs. 1 and 2, the doses were concentrated around the middle of the dose-response curve in order to obtain a precise $\mathrm{ED}_{50}$.

Table 2. The nonlinear log-logistic regression fit of dry weight in the first year. Standard errors in parenthesis, and with upper $95 \%$ confidence interval of $E D_{50}\left(\mathrm{~g}\right.$ ai ha $\left.{ }^{-1}\right)$

\begin{tabular}{c|c|c|c}
\hline Herbicide & Upper limit & Slope & ED50 \\
\hline Sulfosulfuron & $0.36(0.01)$ & $0.87(0.10)$ & $20.6(2.72)$ \\
Mesosulfuron + Idosulfuron & $0.33(0.02)$ & $3.80(2.80)$ & $44.03(4.48)$ \\
Glyphosate & $1.24(0.03)$ & $1.70(0.18)$ & $1751(74.77)$ \\
Mesosulfuron-methyl + Iodosulfuron- & $0.43(0.01)$ & $0.64(0.13)$ & $102.7(18.48)$ \\
methyl-sodium + Diflufenican & $0.35(0.01)$ & $1.33(0.31)$ & $193.8(27.55)$ \\
Clodinafop-propargyl & $0.33(0.01)$ & $1.84(0.31)$ & $61.24(4.55)$ \\
Metsulfuron-methyl + sulfosulfuron &
\end{tabular}

Table 3. The nonlinear log-logistic regression fit of dry weight in the second year. Standard errors in parenthesis, and with upper $95 \%$ confidence interval of $E D_{50}\left(\mathrm{~g}\right.$ ai ha $\left.{ }^{-1}\right)$

\begin{tabular}{c|c|c|c}
\hline Herbicide & Upper limit & Slope & ED $_{\mathbf{5 0}}$ \\
\hline Sulfosulfuron & $0.42(0.01)$ & $0.67(0.08)$ & $20.8(3.43)$ \\
Mesosulfuron + Idosulfuron & $0.42(0.02)$ & $3.02(0.92)$ & $38.29(2.12)$ \\
Glyphosate & $1.20(0.02)$ & $1.69(0.13)$ & $1919(59.59)$ \\
Mesosulfuron-methyl + Iodosulfuron- & $0.39(0.01)$ & $0.74(0.13)$ & $161.2(23.29)$ \\
methyl-sodium + Diflufenican & $0.31(0.01)$ & $1.12(0.16)$ & $92.57(9.58)$ \\
Clodinafop-propargyl & $0.37(0.01)$ & $0.85(0.29)$ & $71.05(16.31)$ \\
Metsulfuron-methyl + sulfosulfuron & &
\end{tabular}


Table 4. $E D_{90}\left(g\right.$ ai ha $\left.{ }^{-1}\right)$ levels of the first experiment with $95 \%$ confidence intervals for the first year

\begin{tabular}{c|c|c}
\hline Herbicide & $\begin{array}{c}\text { Estimate } \\
\text { ED }_{\mathbf{9 0}}\end{array}$ & $\begin{array}{c}\text { Upper limit } \\
\text { ED }_{\mathbf{9 0}}\end{array}$ \\
\hline Sulfosulfuron & 255 & 392 \\
Mesosulfuron + Idosulfuron & 78 & 160.28 \\
Glyphosate & 6349 & 8217.82 \\
Mesosulfuron-methyl + Iodosulfuron-methyl-sodium + & 3077 & 7477.74 \\
Diflufenican & 1005 & 1991.63 \\
Clodinafop-propargyl & 201 & 302.19 \\
Metsulfuron-methyl + sulfosulfuron & & \\
\hline
\end{tabular}

Table 5. $E D_{90}\left(\mathrm{~g}\right.$ ai ha $\left.\mathrm{a}^{-1}\right)$ levels of the second experiment with $95 \%$ confidence intervals for the second year

\begin{tabular}{c|c|c}
\hline Herbicide & $\begin{array}{c}\text { Estimate } \\
\text { ED }_{\mathbf{9 0}}\end{array}$ & $\begin{array}{c}\text { Upper limit } \\
\text { ED }\end{array}$ \\
\hline Sulfosulfuron & 541 & 985.38 \\
Mesosulfuron + Idosulfuron & 79 & 117.13 \\
Glyphosate & 7031 & 8601.46 \\
Mesosulfuron-methyl + Iodosulfuron-methyl-sodium + & 3053 & 6581.38 \\
Diflufenican & 651 & 1045.21 \\
Clodinafop-propargyl & 918 & 2908.76 \\
\hline
\end{tabular}
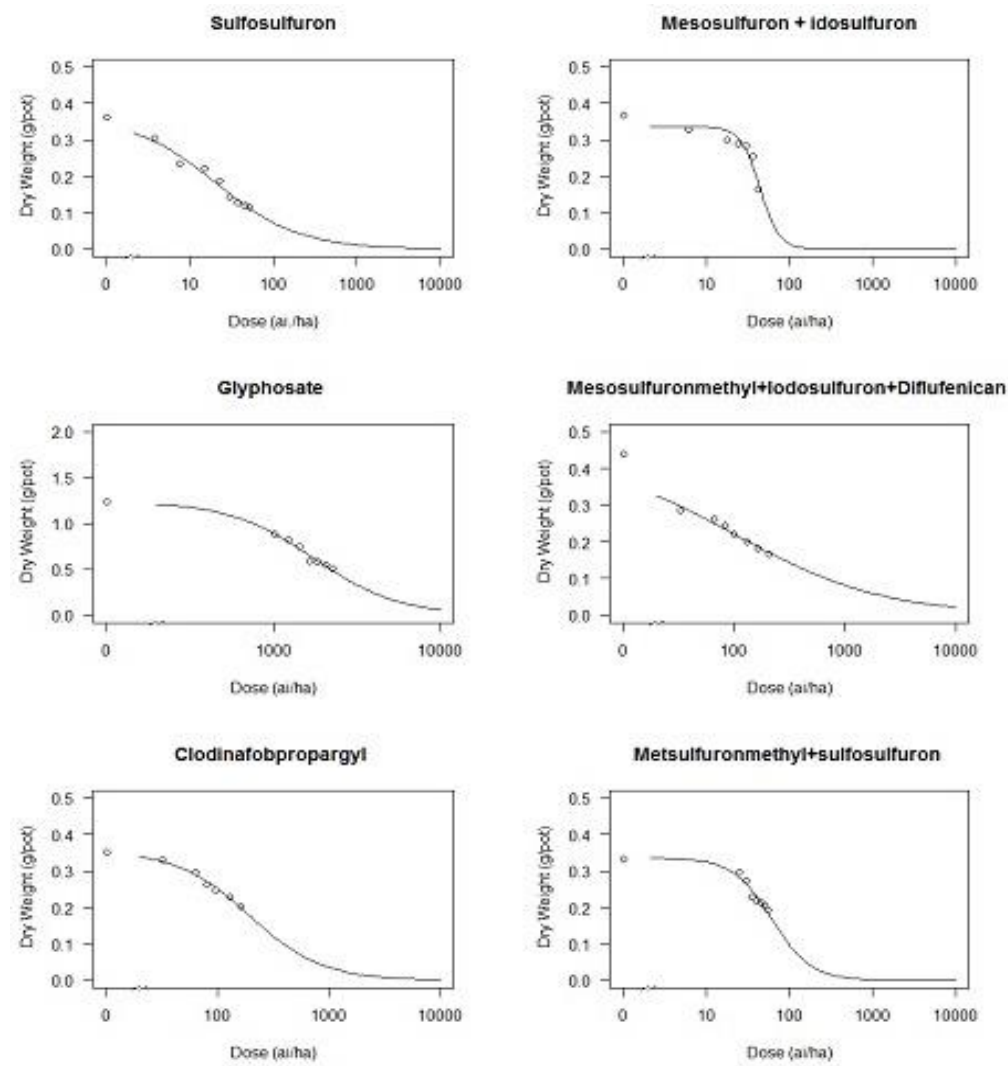

Figure 1. Estimated dose response curves of wild gladiolus to six herbicide treatments. Data shown as dry weight in the first year 


\section{Sulfosulfuron}

The application rates of sulfosulfuron required to reduce wild gladiolus dry matter by 50\% in 2014 and 2015, was 20.6 and $20.8 \mathrm{~g}$ ai ha ${ }^{-1}$, respectively (Tables 2 and 3). Moreover, the application rates of sulfosulfuron required to achieve $90 \%$ wild gladiolus control in 2014 and 2015, were 255 and $541 \mathrm{~g}$ ai ha ${ }^{-1}$, respectively (Tables 4 and 5). In both instances, the ED90 was significantly different from zero even though there were not many observations at the lower part the curve, which is reflected in the precision of ED 90 . The recommended rate for this herbicide in wheat is around $20 \mathrm{~g} \mathrm{ai} \mathrm{ha}^{-1}$ (Table 1). Some studies have shown that the height of weed species and weed biomass at the time of post herbicide applications is an important factor in determining the level of control achieved (Craigmyle et al., 2013; Chahal et al., 2014).
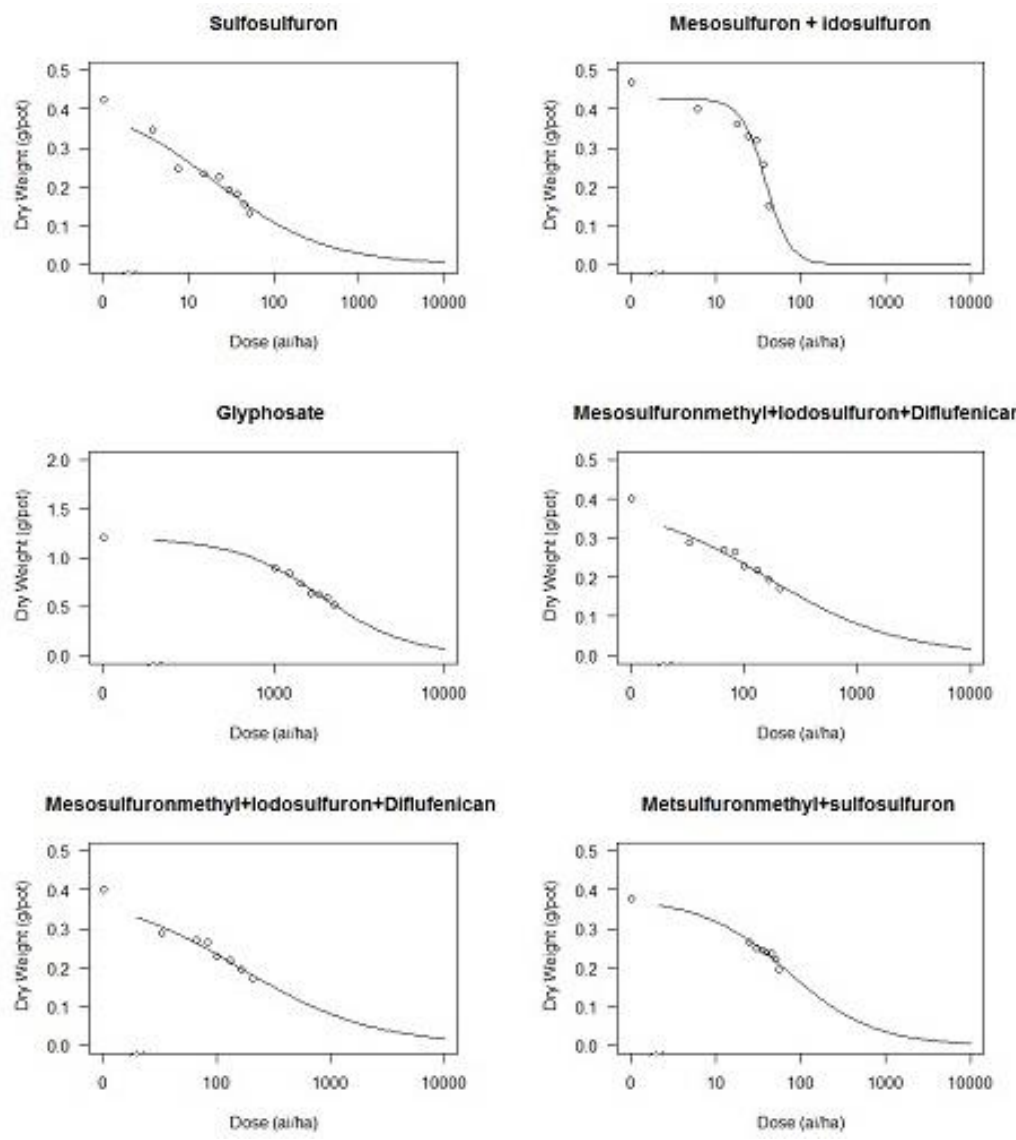

Figure 2. Estimated dose response curves of wild gladiolus to six herbicide treatments. Data shown as dry weight in the second year

\section{Mesosulfuron+idosulfuron}

In the case of mesosulfuron + idosulfuron application, the $\mathrm{ED}_{50}$ increased almost $50 \%$ compared to the Sulfosulfuron (Figs. 1 and 2; and Tables 2 and 3). However, the mixtures had a much steeper dose-response curve than the sulfosulfuron, and thus, the ED90 was much smaller forsulfosulfuron in 2014 and 2015, and were 78 and $79 \mathrm{~g}$ ai ha ${ }^{-1}$, respectively (Tables 4 and 5). The recommended rate for this herbicide in wheat is around $24 \mathrm{~g}$ ai ha ${ }^{-1}$ (Table 1). Kaiser and Gerhards (2015) reported different levels of $\mathrm{ED}_{50}$ for several 
multiple-resistant blackgrass (Alopecurus myosuroides). There was sufficient control of population ALOMY-S with an ED 50 of $2.42 \mathrm{~g}$ ai ha ${ }^{-1}$. ED $\mathrm{ED}_{50}$ values of 21.36 and $9.19 \mathrm{~g}$ ai $\mathrm{ha}^{-1}$, were obtained for ALOMY-R1 and ALOMY-R2, respectively. Why you provide explanation on why you think so?

\section{Glyphosate}

Although the $\mathrm{ED}_{50}$ was rather similar for both sulfosulfuron and mesosulfuron + idosulfuron, it is obvious that glyphosate will require much larger rates to attain $\mathrm{ED}_{50}$ in both years (Figs. 1 and 2; Tables 2 and 3). The relative slopes of the glyphosate response curves were around 1 and were therefore comparatively flat in nature (Figs. 1 and 2). The $\mathrm{ED}_{50}$ of glyphosate was 1751 and $1919 \mathrm{~g}$ ai ha ${ }^{-1}$, in 2014 and 2015, respectively (Tables 2 and 3). In 2014 and 2015, the ED90 values of glyphosate were 6349 and $7031 \mathrm{~g}^{\text {ai ha }}{ }^{-1}$, respectively (Tables 4 and 5). It shows that although effective control of wild gladioluscan be achieved using glyphosate, a rather high dose is required; the recommended rate for this herbicide in wheat is around $1600 \mathrm{~g}^{\text {ai ha }}{ }^{-1}$ (Table 1). Chahal et al. (2015) showed that the shoot biomass curve indicated a 50 and $90 \%$ reduction at 227 and $3704 \mathrm{~g}$ ai ha ${ }^{-1}$, respectively, in 10-cm tall kochia; whereas, the $\mathrm{ED}_{50}$ and $\mathrm{ED}_{90}$ were 612 and 5885 gai ha $^{-1}$, respectively for a $20-\mathrm{cm}$ tall kochia.

\section{Mesosulfuron-methyl + Iodosulfuron-methyl-sodium + Diflufenican}

Results show that the $\mathrm{ED}_{50}$ for this mixture of compounds had higher efficacy of weed control than glyphosate alone (Figs. 1 and 2; Tables 2 and 3). An up to 50\% biomass reduction of wild gladiolus was observed at 102.75 and $161.20 \mathrm{~g}_{\text {ai ha }} \mathrm{ha}^{-1}$, in the first and second year of experiment, respectively. The application rates of Mesosulfuron-methyl + Iodosulfuron-methyl-sodium + Diflufenican required for $90 \%$ reduction in wild gladiolus biomass in 2014 and 2015 were 3077 and $3053 \mathrm{~g}$ ai ha ${ }^{-1}$, respectively. In this case, ED 90 values in two experimental years were similar, but was not significantly different from zero (Tables 4 and 5); the recommended rate for this herbicide in wheat is around $96 \mathrm{~g}$ ai ha $^{-1}$ (Table 1).

\section{Clodinafop-propargyl}

The ED $\mathrm{E}_{50}$ values of clodinafop-propargyl were 193.84 and $92.57 \mathrm{~g}$ ai ha ${ }^{-1}$ in 2014 and 2015 , respectively, with the ED 50 in 2014 being two times higher than in 2015 . However, the $\mathrm{ED}_{50}$ variation between the two years cancelled out, because the rates were not significantly different from zero (Tables 2 and 3). The ED90 values in 2014 and 2015, were 1005 and $651 \mathrm{~g}$ ai ha ${ }^{-1}$, respectively, and the difference is not dramatic considering the precision of the $95 \%$ confidence intervals. The relative slope of the dose-response curves in Figs. 1 and 2 suggest that the herbicide had a similarslope as glyphosate; the recommended rate for this herbicide in wheat is around $60 \mathrm{~g}$ ai ha ${ }^{-1}$ (Table 1). Stagnari et al. (2006) conducted a two years experiment to determine the ED 90 of clodinafoppropargyl for several weed species. The amount of ED 90 for Lolium multiflorum, Avena ludoviciana, and Phalaris minor were 60,32 and $33.6 \mathrm{~g}^{\mathrm{ai} \mathrm{ha}} \mathrm{ha}^{-1}$ in the first year, respectively. In the second year of experiment, the amount of $\mathrm{ED}_{90}$ for Avena ludoviciana and Phalaris minor were 64.5 and $99.8 \mathrm{~g}$ ai ha ${ }^{-1}$, respectively. It indicated that wild gladiolus can tolerate clodinafop-propargyl better than the grasses. 


\section{Metsulfuron-methyl + sulfosulfuron}

Based on the results in Figs. 1 and 2, and Tables 2 and 3, the differences in $\mathrm{ED}_{50}$ was not that dramatic between the first and second experimental years; $E_{50}$ was 61.24 and $71.05 \mathrm{~g}$ ai ha ${ }^{-1}$, respectively. ED 90 was 201.35 and $918.36 \mathrm{~g}$ ai ha ${ }^{-1}$ in 2014 and 2015, respectively. There was vast difference in $\mathrm{ED}_{90}$ between the two years, however, the $\mathrm{ED}_{90}$ values were not different from zero (Tables 4 and 5). This poor precision of the ED 90 could be due to lack of observations to support the lower part of the curve and the much lower relative slope of 0.85 (Table 3). The recommended rate for this herbicide in wheat is $33 \mathrm{~g}$ ai ha ${ }^{-1}$ (Table 1). Izadi-Darbandi and Aliverdi (2015) reported that the amount of $\mathrm{ED}_{50}$ and $\mathrm{ED}_{90}$ of sulfosulfuron+metsulfuron-methyl to control wild barley in wheat field were 26.64 and $41.95 \mathrm{~g}$ ai ha ${ }^{-1}$, respectively.

\section{Discussion}

In our study, results revealed that the highest weed dry weight was associated with glyphosate treatment (Tables 2 and 3). This suggests that even after exposure to glyphosate, the weed is able to grow before the herbicide is distributed throughout whole plant and begin exerting its action. Atlantis, a mixture of mesosulfuron+idosulfuron, resulted in the next highest weed dry weight, while sulfosulfuron produced the lowest weed dry weight, thus indicating high efficacy of sulfosulfuron on the weed compared to other herbicides (Tables 2 and 3). The relative steepness of the dose-response curves for $\mathrm{ED}_{50}$ were different; for example, a sharp decrease in wild gladiolus dry weight was observed after application of sulfosulfuron. Mesosulfuron+idosulfuron curve declined after a steady phase while other herbicide curves dropped slowly (Tables 2 and 3; Figs. 1 and 2). We observed that better control of wild gladiolus was obtained in the second year at the highest dose for all herbicides (Fig. 2). It is important to note that optimum efficacy is influenced by weed size, so that when the size of the weed is bigger, the control will be lower (Everitt and Keeling, 2007; Robinson et al., 2012).

Generally, among all herbicides tested, sulfosulfuron had the lowest $\mathrm{ED}_{50}$ in both years, 2014 (20.6 $\left.\mathrm{g}_{\text {ai }} \mathrm{ha}^{-1}\right)$ and 2015 (20.8 $\left.\mathrm{g}_{\text {ai ha }}{ }^{-1}\right)$ (Tables 2 and 3); while glyphosate had the highest ED 50 in 2014 (1751.99 $\mathrm{g} \mathrm{ai} \mathrm{ha}^{-1}$ ) and 2015 (1919.93 $\mathrm{g}^{\text {ai ha }}{ }^{-1}$ ) (Tables 2 and 3). This suggests that sulfosulfuron and glyphosate were the highest and lowest performing herbicides with respect to wild gladiolus control. In the case of ED90, mesosulfuron+idosulfuron and glyphosate had the highest and lowest influence on the control of wild gladiolus. The ED 90 values of mesosulfuron+idosulfuron were 78 and $79 \mathrm{~g}$ ai $\mathrm{ha}^{-1}$ in 2014 and 2015, respectively (Tables 4 and 5). Also, the ED90 values of glyphosate were 6349 and $7031 \mathrm{~g}$ ai ha ${ }^{-1}$ in 2014 and 2015, respectively (Tables 4 and 5).

\section{Conclusion}

The greenhouse experiment with six different herbicide treatments identified sulfosulfuron to be the most effective in controlling wild gladiolus. Although a few herbicides were identified to be most effective, it is crucial that we use incorporate the use of different herbicides with various modes of action to prevent or manage herbicide resistance in wild gladiolus. This will encourage herbicide rotation and tank mixing herbicides with different modes of action for effective and sustainable weed control. Further research on studying the effects of natural environmental conditions on the 
efficacy of herbicides used in this study with regards to wild gladiolus control is under evaluation.

Acknowledgements. The authors would like to thank Dr. Jens Carl Streibig for his assistance with statistical analysis, and Dr. Rouzbeh Zangoueinejad for his support in formatting the manuscript.

Disclosure Statement. The authors declare no conflict of interests.

\section{REFERENCES}

[1] Alebrahim, M. T., Zangoueinejad, R., Tseng, T. M. (2017): Biochemical and Molecular Knowledge about Developing Herbicide-Resistant Weeds. Chapter 5. - In: Pacanoski, Z. (eds.). Herbicide resistance in Weeds and Crops. - Intechopen, Zagreb, Croatia. 101-132.

[2] Aghaie, P., Kazemeini, S. A., Majd, R., Alebrahim, M. T. (2013): Role of Phosphorus in Maize (Zea mays L.) Competitiveness against Velvetleaf (Abutilon theophrasti). International J. Agron. Plant Produc. 4(9): 2323-2329.

[3] Baird, D. D., Upchurch, R. P., Homesley, W. B., Franz, J. E. (1971): Introduction of a new broad-spectrum post-emergence herbicide class with utility for herbaceous perennial weed control. - Proc North Cent Weed Control Conf. 26: 64-68.

[4] Chahal, P. S., Kruger, G., Blanco-Canqui, H., Jhala, A. J. (2014): Efficacy of preemergence and post-emergence soybean herbicides for control of glufosinate-, glyphosate, and imidazolinone-resistant volunteer corn. - J. Agri. Sci. 6: 131-140.

[5] Chahal, P. S., Aulakh, J. S., Rosenbaum, K., Jhala, A. J. (2015): Growth Stage Affects Dose Response of Selected Glyphosate-Resistant Weeds to Premix of 2,4-D Choline and Glyphosate (Enlist Duo ${ }^{\text {TM }}$ Herbicide*). - J Agric Sci. 7: 1-10.

[6] Craigmyle, B. D., Ellis, J. M., Bradley, K. W. (2013): Influence of weed height and glufosinate and 2,4-D combinations on weed control in soybean with resistance to 2,4-D. - Weed Technol. 27: 271-280.

[7] Dahlgren, R. M. T. (1985): The Families of the Monocotyledons. - Springer Verlag, Berlin, Heidelberg.

[8] Davis, P. H. (1984): Flora of Turkey and the East Aegean Islands. - Vol. 8. Edinburgh University Press, UK, 441-450.

[9] Deihimfard, R., Zand, E. (2005): Evaluating environmental impacts of herbicides on wheat agroecosystems in the provinces of Iran using EIQ model. - Environmental Science. 6: 19.

[10] Devine, M. D., Shimabukuro, R. H. (1994): Resistance to acetyl coenzyme A carboxylase inhibiting herbicides. - In: Powles, S. B., Holtum, J. A. M. (eds.) Herbicide resistance in plants: biology and biochemistry. Lewis, Boca Raton 141-169.

[11] Ebadi, A., Razmjoo, J., Ghanji, M., Sajed, K., Shahbazi, K., Davari, M. (2004-2007): Investigating the Control of Weed Control of Wild Gladiulos sp. and Sophoraalopecuriodes in Wheat and Cereal Cultivated Fieldsin Germi, Bile savar (Moghan) and Khalkhal (Ardabil). - Organization of Management and Planning of Ardebil Province.

[12] Ebadi, A., Parmoon, G., Samadi Calkhoran, E., Sajed, K. (2015): Evaluation of the effect of mixture of herbicides on weeds control in rainfed bread wheat (Triticum aestivum L.) in Ardabil. - Iranian Journal of Crop Sciences 17(3): 179-192. (In Persian).

[13] Everitt, J. D., Keeling, J. W. (2007): Weed control and cotton (Gossypium Hirsutum) response to preplant applications of dicamba, 2,4-D, and diflufenzopyr plus dicamba. Weed Technol. 21: 506-510.

[14] Franz, J. E., Mao, M. K., Sikorski, J. A. (1997): Glyphosate: a unique global herbicide. ACS Monograph 189, American Chemical Society, Washington, DC. 
[15] Goldblatt, P., Manning, J. C., Bernhardt, P. (2001): Radiation of pollination systems in Gladiolus (Iridaceae: Ixioideae) in southern Africa. - Annals of the Missouri Botanical Gardens. 97: 317-344.

[16] Gruys, K. J., Sikorski, J. A. (1999): Inhibitors of tryptophan, phenylalanine, and tyrosine biosynthesis as herbicides. - In: Singh, B. K. (ed.) Plant amino acids: biochemistry and biotechnology. Marcel Dekker, New York 357-384.

[17] Izadi-Darbandi, E., Aliverdi, A. (2015): Optimizing Sulfosulfuron and Sulfosulfuron Plus Metsulfuron-methyl Activity when Tank-Mixed with Vegetable Oil to Control Wild Barley (Hordeum spontaneum Koch.). - J. Agr. Sci. Tech. 17: 1769-1780.

[18] Kaiser, Y. I., Gerhards, R. (2015): Degradation and Metabolism of Fenoxaprop and Mesosulfuron + Iodosulfuron in Multiple Resistant Blackgrass (Alopecurusmyosuroides). - Gesunde Pflanzen. 67: 109-117.

[19] Khalaghani, J. (2008): Advanced study for estimation of yield loss due to weeds in wheat fields. - Final report of project, Iranian Research Institute of Plant Protec. 76.

[20] LaRossa, R. A., Schloss, J. V. (1984): The sulfonylurea herbicide sulfometuron methyl is an extremely potent and selective inhibitor of acetolactate synthase in Salmonella typhimurium. - J Bioi Chern. 25: 8753-8757.

[21] Majd, R., Mohammaddust chamanabad, H. R., Zand, E., Mohebodini, M., Karbalaei Khiavi, H., Alebrahim, M. (2017): Evaluation of some ecophysiological factors for sustainable management of Wild Gladiolous (Gladiolus segetum). - J. Agroecol. 7(1): 172185. (In Persian).

[22] Rashed Mohassel, H., Najafi, H., Akbarzadeh, M. (2001): Biology and Weed Control. Ferdowsi University Press, Mashhad. 350.

[23] Ray, T. B. (1984): Site of action of chlorsulfuron: inhibition of valine and isoleucine biosynthesis in plants. - Plant Physiol. 75: 827-831.

[24] Ritz, C., Cedergreen, N., Jensen, J. E., Streibig, J. C. (2006): Relative potency in nonsimilar dose-response curves. - Weed Sci. 54: 407-412.

[25] Robinson, A. P., Simpson, D. M., Johnson, W. G. (2012): Summer annual weed control with 2,4-D and glyphosate. - Weed Technol. 26: 657-660.

[26] Shaner, D. L., Anderson, P. C., Stidham, M. A. (1984): Potent inhibitors of acetohydroxyacid synthase. - Plant Physiol. 76: 545-546.

[27] Shimizu, T., Nakayama, I., Nakao, T., Nezu, Y., Abe, H. (1994): Inhibition of plant acetolactate synthase by herbicides, pyrimidinylsalicylic acids. - J Pestic Sci. 19: 59-67.

[28] Stagnari, F., Onofri, A., Covarelli, G. (2006): Influence of vegetable and mineral oils on the efficacy of some post-emergence herbicides for grass weed control in wheat. - J. Pestic. Sci. 31: 339-343.

[29] Streibig, J. C., Rudemo, M., Jensen, J. E. (1993): Dose-response curves and statistical models. Chapter 3. - In: Streibig, J. C., Kudsk, P. (eds.) Herbicide Bioassays. CRC Press, Boca Raton, Florida, USA. 29-55.

[30] Subramanian, M. V., Gerwick, B. C. (1989): Inhibition of acetolactate synthase by triazolopyrimidines. - ACS Symp Ser 389, Washington, DC. 277-288.

[31] Tahmasebi, B. K., Alebrahim, M. T., Roldán-Gómez, R. A., Martins da Silveira, H., Bianco de Carvalho, L., Alcántara-de la Cruz, R., De Prado, R. (2018): Effectiveness of alternative herbicides on three Conyza species from Europe with and without glyphosate resistance. Crop Protec. 112: 350-355.

[32] Zand, E., Baghestani, M. A., Nezamabadi, N., Shimi, P., Mousavi, S. K. (2017): A guide to chemical control of weeds in Iran. - J.D.M press, Iran, Mashhad. 